\title{
Ethnobotany of Indigenous Saraguros: Medicinal Plants Used by Community Healers "Hampiyachakkuna" in the San Lucas Parish, Southern Ecuador
}

\author{
José M. Andrade, ${ }^{1}$ Hernán Lucero Mosquera, ${ }^{2}$ and Chabaco Armijos ${ }^{1}$ \\ ${ }^{1}$ Department of Chemistry, Universidad Técnica Particular de Loja, P.O. Box 11-01-608, Loja, Loja Province, Ecuador \\ ${ }^{2}$ Department of Natural Sciences, Universidad Técnica Particular de Loja, P.O. Box 11-01-608, Loja, Loja Province, Ecuador \\ Correspondence should be addressed to José M. Andrade; jmandrade@utpl.edu.ec
}

Received 15 February 2017; Revised 21 April 2017; Accepted 21 May 2017; Published 4 July 2017

Academic Editor: Horacio Bach

Copyright (C 2017 José M. Andrade et al. This is an open access article distributed under the Creative Commons Attribution License, which permits unrestricted use, distribution, and reproduction in any medium, provided the original work is properly cited.

This paper reports the results of an ethnobotanical survey on the use of medicinal plants by community healers "Hampiyachakkuna" in the San Lucas Parish, province of Loja, Ecuador. A particular ethnic group, the indigenous Saraguros, inhabits this region. This study reports 183 plant species used in 75 different curative therapies by the Saraguro healers.

\section{Introduction}

The Saraguros are one of the Kichwa indigenous communities of Ecuador. Although their origin is uncertain, they are considered to have been forced by the Incas to reach Ecuador from far away. A commonly accepted theory on how they reached south Ecuador is as a result of an "ethnical mobilization," a common practice established by the great Inca Tupac Yupanqui. This strategy was used in order to secure the peace inside the Empire. As such, and according to Uhle [1], a small group of Paltas, the autochthonous inhabitants of the Loja region in south Ecuador, were transferred to Bolivia; and at the same time, a certain number of inhabitants of the Bolivian Highland Plateau were relocated in south Ecuador [2]. Nowadays, the Saraguros are normally settled in communitarian land in the southern Ecuador provinces of Loja and Zamora Chinchipe. In the canton of Loja, the Saraguros live in the San Lucas Parish, where this research was conducted.

The Saraguros are one of the best-organized ethnical groups in Ecuador and have conserved many aspects of their ancient culture and traditions for centuries. They demonstrate the latter by preserving their typical dressing, language, religion, gastronomy, architecture, social habits, and medical practices [3]. Among their medical practice traditions, this ethnic group is known for the use of medicinal plants in their own health care system. In fact, the use of these plants as therapeutic agents is an important feature of traditional indigenous medicine and is still practiced within the Saraguro community [4]. In particular, the Saraguros are highly recognized for the development of optimization techniques that help them select natural/plant resources to be used in their health care practices [5].

The community of healers locally known as "Hampiyachakkuna" maintains the ancient medical treatments of the Saraguros. The "Yachak" or "Hampi yachakkuna" is the person who knows the curative properties of plants, animals, and/or minerals. Under the Andean cosmovision of the Saraguros ethnical group, the diseases they treat are thought to be produced by either cold or heat [6]. As such, their natural medicines are classified as hot and fresh [7]; and depending on the nature of the patient's condition, different plants are selected for the treatment in accordance with this classification. However, although the knowledge regarding the usage of plants for medicinal practices has been transmitted orally from generation to generation [8], the Saraguros are experimenting cultural changes that threaten the preservation of their ancestral knowledge. These cultural changes lead to negative consequences such as the loss of traditional knowledge, a decline in the use of natural resources, and changes in the patterns of food intake, medical treatment, and, furthermore, 
their cosmovision. For these reasons, there is an urgent need to document and preserve their invaluable knowledge [9].

In this sense, a number of ethnobotanical studies have been conducted in Ecuador. [10-16]. More recently, a series of important contributions to ethnobotanical research in the South of Ecuador have been published $[17,18]$. For example, there are studies related to the use of wild fruits as alimentary supplements [19], the documentation of the herbaceous plants of Vilcabamba [20], and of medicinal plants used in the province of Loja [21]. In the latter, the existence of more than 200 medicinal plants was reported. In the Saraguro region, only few ethnobotanical studies have reported the usefulness of different natural plants in a variety of applications [22-24]. However, to date, a thorough documentation of the plants used as medicinal resources by the healers of the Saraguro ethnical group, which is the motivation for this investigation, has not been reported.

Because of the increasing recognition of the importance of the different medicinal species used by the Saraguros and in an effort to preserve their knowledge, in this work we seek to contribute to the conservation strategy on the sustainable uses of the Ecuadorian medicinal biodiversity. The latter is considered a fundamental step in order to raise awareness of its cultural value and the importance of its preservation. By doing that, we intended to safeguard the popular knowledge concerning natural medicinal plants and to provide a baseline for future actions regarding scientific research programs, environmental education, social awareness, and sustainable natural resources exploitation. As such, this study was conducted under a technical and scientific cooperation among the Universidad Técnica Particular de Loja (UTPL), the Dirección Provincial de Salud de Loja (DPSL), and the Saraguros Healers Council (Consejo de Sanadores de Saraguro) with the objective of recognizing and recovering the traditional knowledge of herbal medicinal resources used by the Saraguro community. The results of this research also aim at becoming a starting point to attract the attention of national and international tourists, in order to promote a selfsustaining development of the Saraguro community.

\section{Methodology}

This study was carried out in the San Lucas Parish in the south Ecuadorian province of Loja (Figure 1). San Lucas is limited to the north with the Saraguro Canton and the "Loma de Oro" mountain, to the south with the Jimbilla parish by the Bunque and Puruzhuma Rivers, to the east with the Loja-Zamora Chinchipe provincial limits and the Imbana Mountain, and to the west with the Santiago parish. San Lucas has an area of 15.900 ha and a population of approximately 4,296 inhabitants [12]. The dominant ecosystem in the zone is classified as lower montane-humid forest (hf-LM) according to Holdrige classification system. It is located at an average elevation of 2,525 $\mathrm{m}$ a.s.l and has an irregular topography. The study area has a temperate climate, with temperature ranging between 12 and $18^{\circ} \mathrm{C}$ along the year [12]. Annual precipitation amounts range between 600 and $1,000 \mathrm{~mm} \mathrm{yr}^{-1}$. The rainfall regime is semihumid with low seasonality.

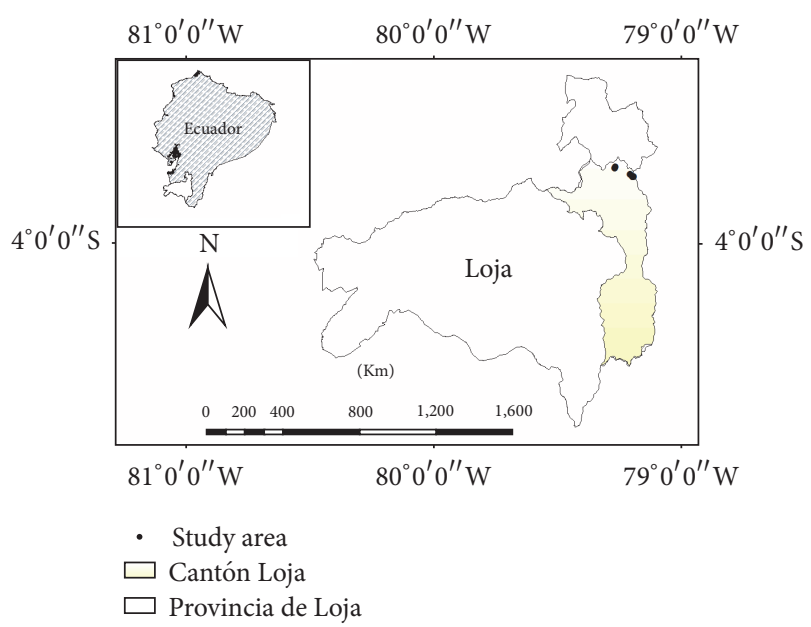

FIgURE 1: Geographical location of the San Lucas Parish, indicating the places of collection of medicinal species.

This research was carried out during 11 field trips conducted during the period June-September 2010. During these field visits, interviews with four key informants (i.e., healers) from the Saraguro community regarding the medicinal plants they use in their practices and their applications were carried out. These healers were a midwife "Wachakhampiyachak," a herbalist "Yurakhampiyachak," a bone-healer "Kakuyhampiyachak," and a visionary "Rikuyhampiyachak." All of them are inhabitants of San Lucas community (Table 1) (Figure 2).

In the Saraguro community, the midwifes (locally known as "parteras" or wachak in Kichwa) watch over the health of women in labor ("parturienta" in Spanish), prior, during, and after the child's birth, as well as during the first years of the newborn's life. They are mainly recognized for using medicinal plants normally grown in her own orchard, which facilitates their work. The herbalists (locally known as "hierbateros") treat diseases with symptomatology of organic type. These include headache, stomach ache, articulation pain, fever, and/or allergies. The "hierbateros" mainly use medicinal resources collected in high-elevation mountainous areas. As such, differently from the "parteras," they use larger amounts of herbal wild species during their practices. The bone-healers (locally known as "sobador") is an empirical traumatologist who uses medicinal plants and the fat of different animals to treat the rupture of bones, sprains, and dislocations. The "visionario" (locally known as "Yachak") are specialized in the diagnosis and treatment of diseases of supernatural nature (e.g., evil eye, fright (or "susto" in Spanish)), but also the aforementioned diseases of organic nature. They are particularly recognized for their expertise in the preparation of psychoactive potions using hallucinogen natural plants and depending of the Yachak expertise and knowledge the use of additional nonhallucinogen plants that act as psychoactive additives. For example, on the use of wamingas and trencillas (Huperzia spp.) for the preparation of the hallucinogenic cactus San Pedro (Echinopsis pachanoi) [11]. Although the practices of these community healers are 
TABLE 1: Places of collection of medicinal species used by community healer.

\begin{tabular}{lcccc}
\hline \multirow{2}{*}{ Place of collection } & \multicolumn{3}{c}{ Community healer } & Bone-healer \\
\hline Acacana & Visionary & $\mathrm{x}$ & $\mathrm{x}$ & $\mathrm{x}$ \\
Pichic & & $\mathrm{x}$ & $\mathrm{x}$ & $\mathrm{x}$ \\
Ingapirca & $\mathrm{x}$ & & \\
Inguera & $\mathrm{x}$ & & \\
Aguarongo & $\mathrm{x}$ & & \\
Plan de Duco & $\mathrm{x}$ & & \\
\hline
\end{tabular}

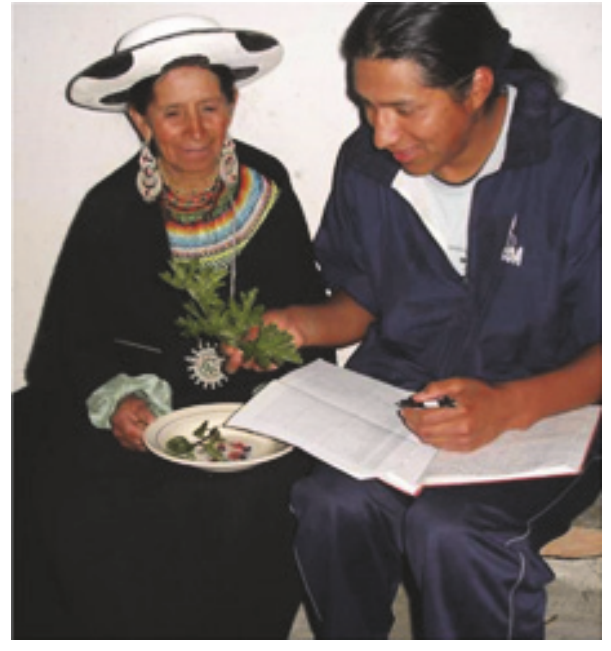

(a)

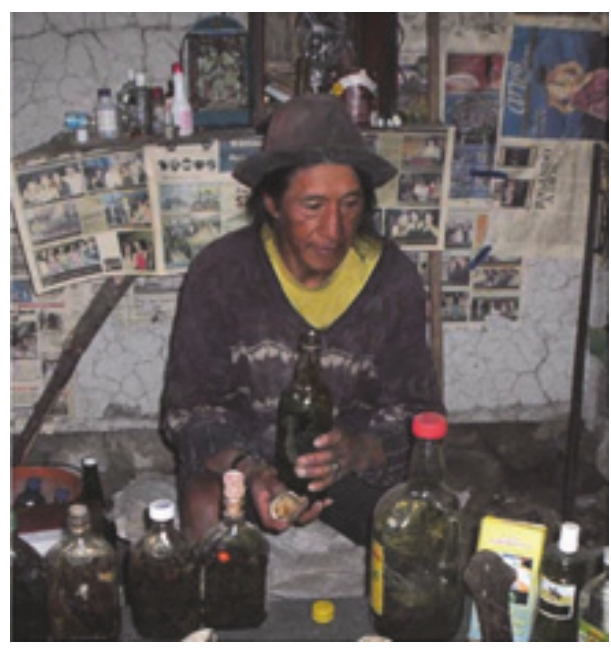

(c)

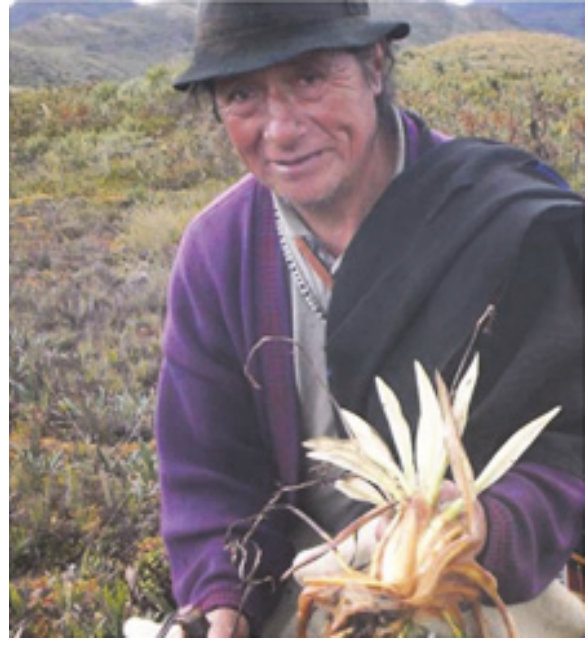

(b)

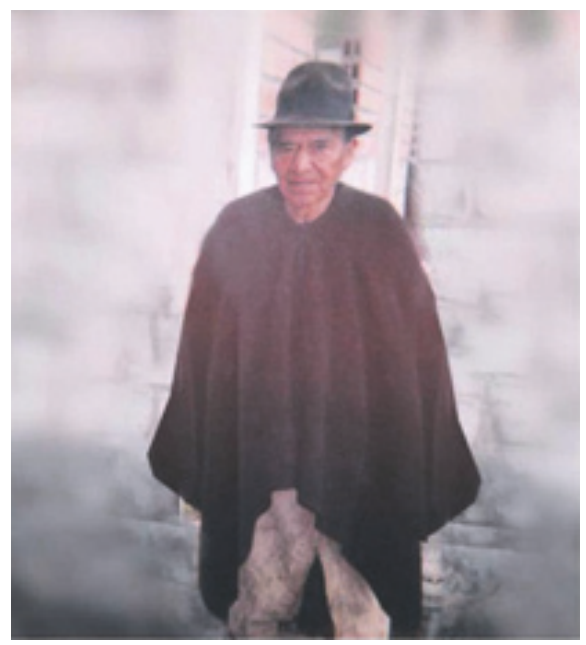

(d)

Figure 2: Community healers from San Lucas Parish: (a) midwife "Wachakhampiyachak" during an interview with one of the coauthors; (b) herbalist "Yurakhampiyachak"; (c) visionary "Rikuhampiyachak"; and (d) bone-healer "Kakuyhampiyachak."

highly trusted and recognized as effective within the Saraguro community, when they detect serious conditions in the health of a patient, they immediately transfer the patient to a health center or hospital.

The informants were contacted through authorized representatives of the Department of Indigenous Health (Departamento de Salud Indígena) of the Loja City Health Direction.
The informants were between 60 and 80 years old, with at least 25 years of experience in the use of medicinal plant species. The consent of each of the interviewed Saraguro healers was obtained before starting the study and reporting the results. Their knowledge of traditional medicine was inherited from ancestors and close relatives. The information collected during the interviews with the healers was related to 
the different uses, application forms, preparation, method/s of collection, parts, and spread of the different plants used by each of them as medicinal resources.

In addition, the medicinal plants species used by each of the healers within the San Lucas Parish were collected. The species were classified according to the Red Book of endemic plants of Ecuador [21] and the Catalogue of the Vascular Plants of Ecuador [25]. After their classification, the collected specimens were deposited in the herbarium of the Plant of Natural Products (Planta de Productos Naturales) of the Universidad Técnica Particular de Loja for future studies. The qualitative evaluation and quantitative information collected of all species were tabulated and analyzed with their vernacular names, occurrence, growing places, therapeutically applications, parts used, plants habit development, and forms of preparation as described by each informant. The scientific nomenclature was recorded according to the Catalogue of the Vascular Plants of Ecuador [25]. This research was conducted under permission of the Ministerio del Ambiente del Ecuador (MAE-N ${ }^{\circ}$ 001-IC-FLO-DBAP-VS-DRLZCH-MA). Additionally, voucher specimens were prepared and deposited in Herbarium of the Universidad Técnica Particular de Loja. Date of plant species, vernacular name, scientific name and family, medicinal use, parts used and modality of preparation, form of administration, and the species used for each "Hampi Yachak" are reported in Tables 4 to 7 .

\section{Results and Discussion}

In this ethnobotanical survey, we identified 183 plants used by the community healers "Hampi yachakkuna" of the Saraguro ethnic in the San Lucas Parish. These were grouped into: 68 families, 129 genera, and 179 species. The most representative families were Asteraceae (30 species); Lamiaceae (14 species), Arecaceae ( 9 species), Solanaceae and Geraniaceae ( 8 species each), Amaryllidaceae and Brassicaceae (7 species each), and Piperaceae, Lycopodiaceae, and Ericaceae (6 species each). In relation to the treated diseases we found that 47 species are used for mythological treatments, 24 species for nervous system treatments, 13 species for cold treatments, 12 species for infection treatments, 9 species for general malaise treatments, and 8 species for inflammatory treatments of the liver and kidneys. These results are corroborated by the studies of [26-28]. As reported by [3,5], as a result of their ancient Andean world view, supernatural and mythological diseases are the most commonly treated conditions by the Saraguro healers.

The type of species used by the healers, with exception of the midwifes ("Wachakhampiyachak") who use a large amount of self-cultivated species, are wild species (57.4\%). These species are generally collected at high-elevation in the highlands surrounding the parish. About the vegetative organ of the plants used, we found that the highest proportion corresponds to the use of the whole plant (30.1\%), followed by the branches (21.9\%), flowers (18.6\%), leaves (16.4\%), bark (2.2\%), seeds (1.1\%), and tubers (0.6\%). These results contrast with those documented by [29] in the San Lucas Parish, who reported that the most commonly used part of the plants are the leaves. With regard to the preparation of the medicinal
TABLE 2: Knowledge on the propagation of species.

\begin{tabular}{lcc}
\hline Propagation & Number of species & Percent (\%) \\
\hline Unknown & 101 & 55.19 \\
Sexual & 32 & 17.49 \\
Asexual & 50 & 27.32 \\
\hline Total & 183 & 100.00 \\
\hline
\end{tabular}

treatment products, crushing of the plants or their parts was determined as the most commonly applied method to process the rough plant tissues $(28.4 \%)$, because it allows for a more effective treatment of the diseases according to the key informants. This method is followed by boiling the plant tissues in water $(27.9 \%)$, infusions $(25.7 \%)$, and their direct use $(18 \%)$ as has been previously reported by [28].

The interviewees did not know the form of reproduction of the majority of the species documented in the study (55.2\%). From the ones they knew, 27.3\% have an asexual reproduction and $17.5 \%$ have a sexual reproduction (Table 2). Only $29 \%$ of the total number of the registered species (53 species) have not been previously reported in scientific investigations of phytochemical character and their pharmacological activity. In contrast, 71\% (130 species) have registered studies of pharmacological and phytochemical nature. Regarding the administration and/or application of medicinal preparations, five procedures were identified: oral administration (110 species), topical administration (45 species), administration during water baths (17 species), administration during rituals (locally known as "limpias") (9 species), and administration during steam baths (2 species).

Of the total screened plants, $55.2 \%$ are native, $37.2 \%$ are introduced, and $7.7 \%$ are endemic. Similar results have been reported in the paste $[20,30]$. From the 13 endemic species reported (Table 3), 2 species are used by the midwife, 3 species by the herbalist, 6 species by the visionary, and 2 species by the bone-healer. From the total number of species used by the healers, 96 are used by the visionary, 69 by the herbalist, 52 by the midwife, and 12 by the bones healer (Figure 3). It is important to mention that some of the species are used by more than one Yachak.

In relation to the type of plants used by the healers, the results show that $61.8 \%$ correspond to herbs (113 species), $25.7 \%$ correspond to shrubs (47 species), 7.1\% correspond to trees (13 species), 3.8\% correspond to lianas (7 species), and the rest correspond to two parasitic and one aquatic species [31] (Figure 4). From these, the species grown in the "páramo" (tropical alpine grassland ecosystem) belong to Huperzia and Lycopodium genera as was previously reported by [32]. Out of the total species registered, two of them (Bejaria resinosa and Huperzia) have been studied in detail, showing a high potential of the Saraguro flora as a source of novel secondary metabolites and biologically active plants extracts as has been previously reported [33-35]. Finally, a summary of the documented plant species used by the different healers that include information of their scientific name, way of preparation, and administration is reported in Tables 4-7. 
TABLE 3: Endemic species reported.

\begin{tabular}{lcc}
\hline Common name & Scientific name & Category \\
\hline Pena de cerro & Bejaria subsessilis Benth. & Vulnerable \\
Suelda pequeña & Dendrophthora fastigiata Kuijt. & In danger \\
Chuquir agua & Diplostephium oblanceolatum S. F. Blake & Almost threated \\
Sacha pena & Fuchsia hypoleuca I. M. Johnst. & In danger \\
Wuaminga verde pequeño & Huperzia austroecuadorica B. Øllg. & Vulnerable \\
Shallshón & Lepechinia paniculata (Kunth) & Vulnerable \\
Pena rojo de monte & Siphocampylus scandens (Kunth). G. Don & Least preoccupation \\
Pegac chilca & Ageratina dendroides (Spreng) R. & Vulnerable \\
Sarcillo sacha & Brachyotum scandens (Bonpl.) Triana. & Least preoccupation \\
Monte de baño & Diplostephium juniperinum Cuatrec & In danger \\
Suelda grande & Phoradendron parietarioides Trel. & Not evaluated \\
Sacha algodón & Achyrocline hallii Hieron. & Vulnerable \\
Sp flor morado & Salvia leucocephala Kunth & Vulnerable \\
\hline
\end{tabular}

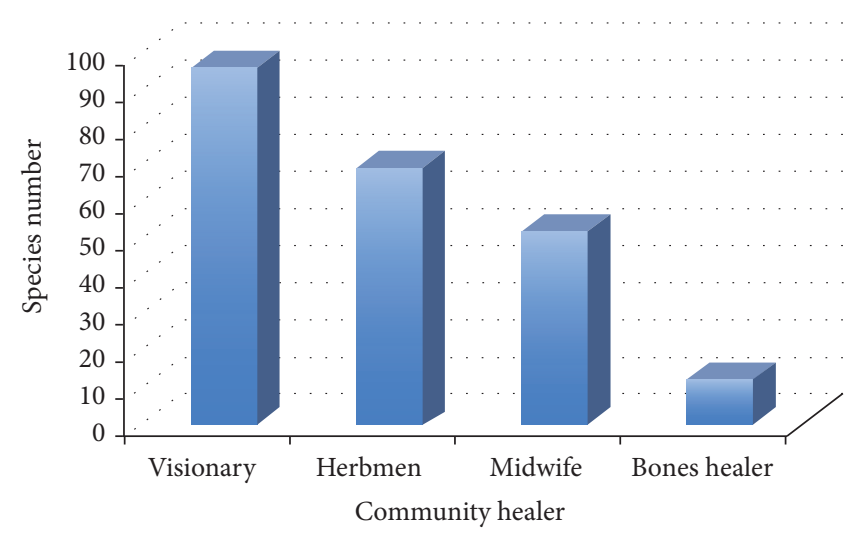

FIGURE 3: Number of species used by each community healer.

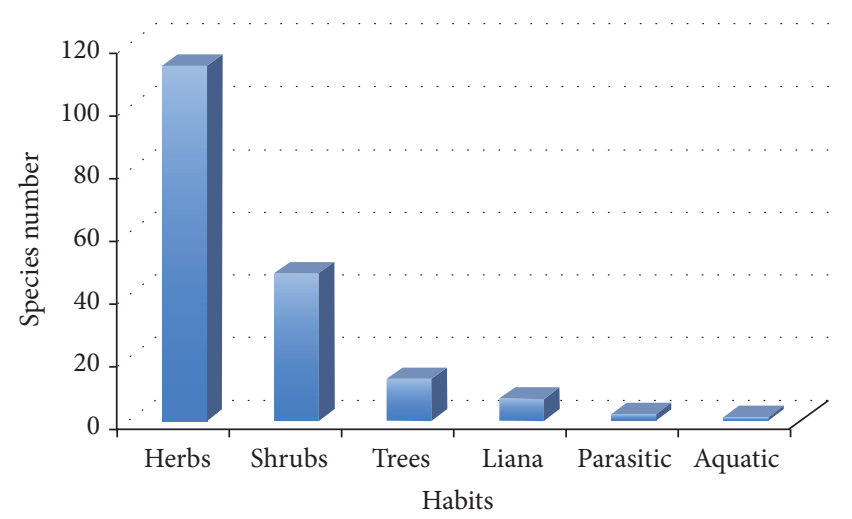

Figure 4: Number of species in relation to their habit.

\section{Conclusions}

In this study we collected, organized, and documented the natural plants used in traditional healing practices of the Saraguro community of the San Lucas Parish in south Ecuador. We achieved this according to the directions of the
World Health Organization (OMS), which is one of the prioritized strategic research lines of the National Secretariat for Science and Technology of Ecuador (SENESCYT), that is, to strengthen and enhance the recovery of ancestral knowledge in coexistence with scientific knowledge. We documented the existence of 183 species used in 75 different curative therapies by four key community healers of the Saraguro ethnic group: a midwife, an herbalist, a bone-healer, and a visionary.

This research conducted in collaboration with the members of the native Saraguro community constitutes a baseline study to help promote the preservation of this ancient medicinal knowledge by a thorough documentation of the natural resources and processing methods used. Moreover, we hope the results of this study motivate young generations to envision the potential of the use and application of traditional knowledge in medicinal practices. Finally, this scientific research and the results here reported aim at preserving and enhancing, as much as possible, a culture of the practice of natural ancient medicinal science, while preserving the environment, nature, life, culture, and sovereignty of the Saraguro people. 


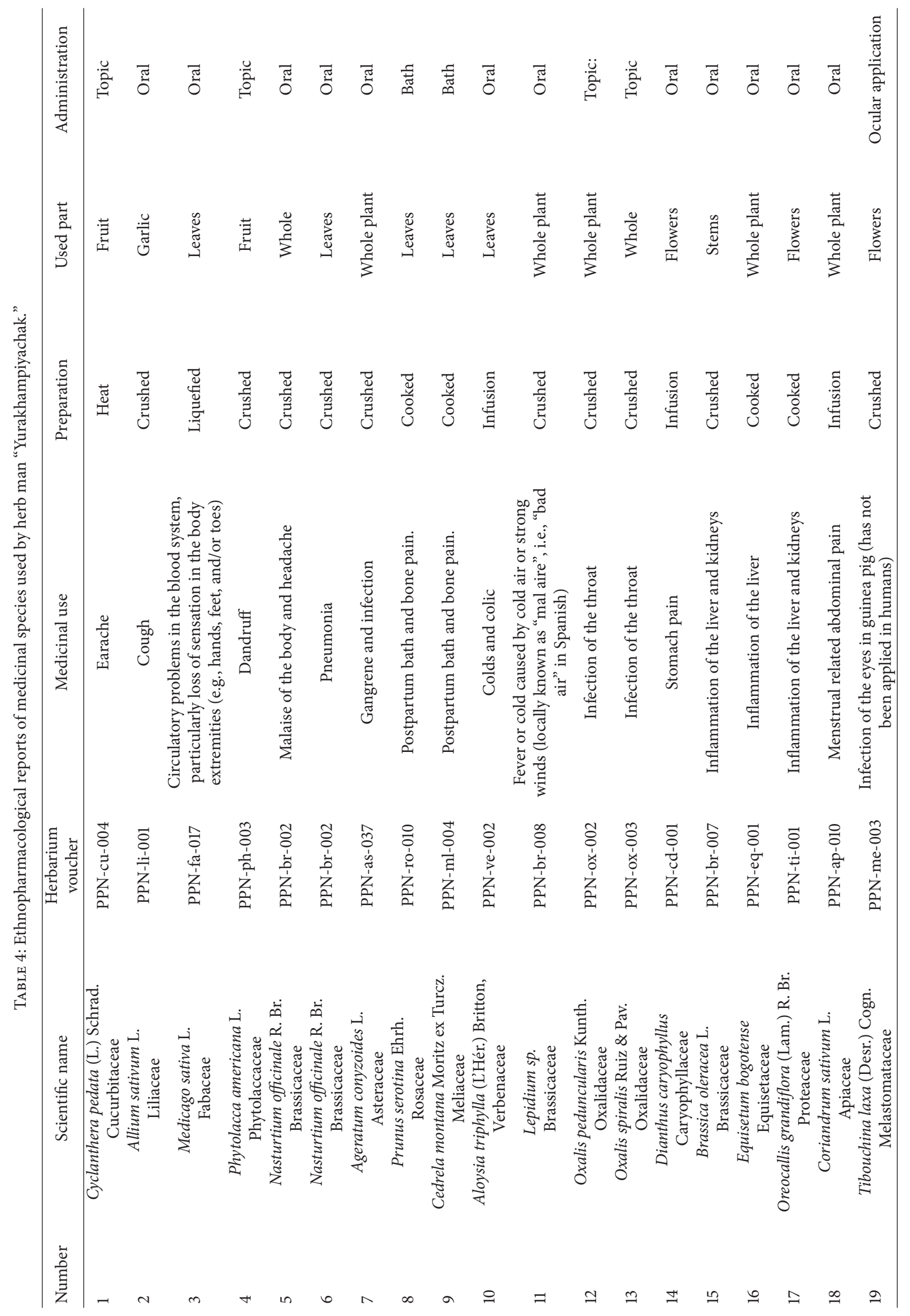




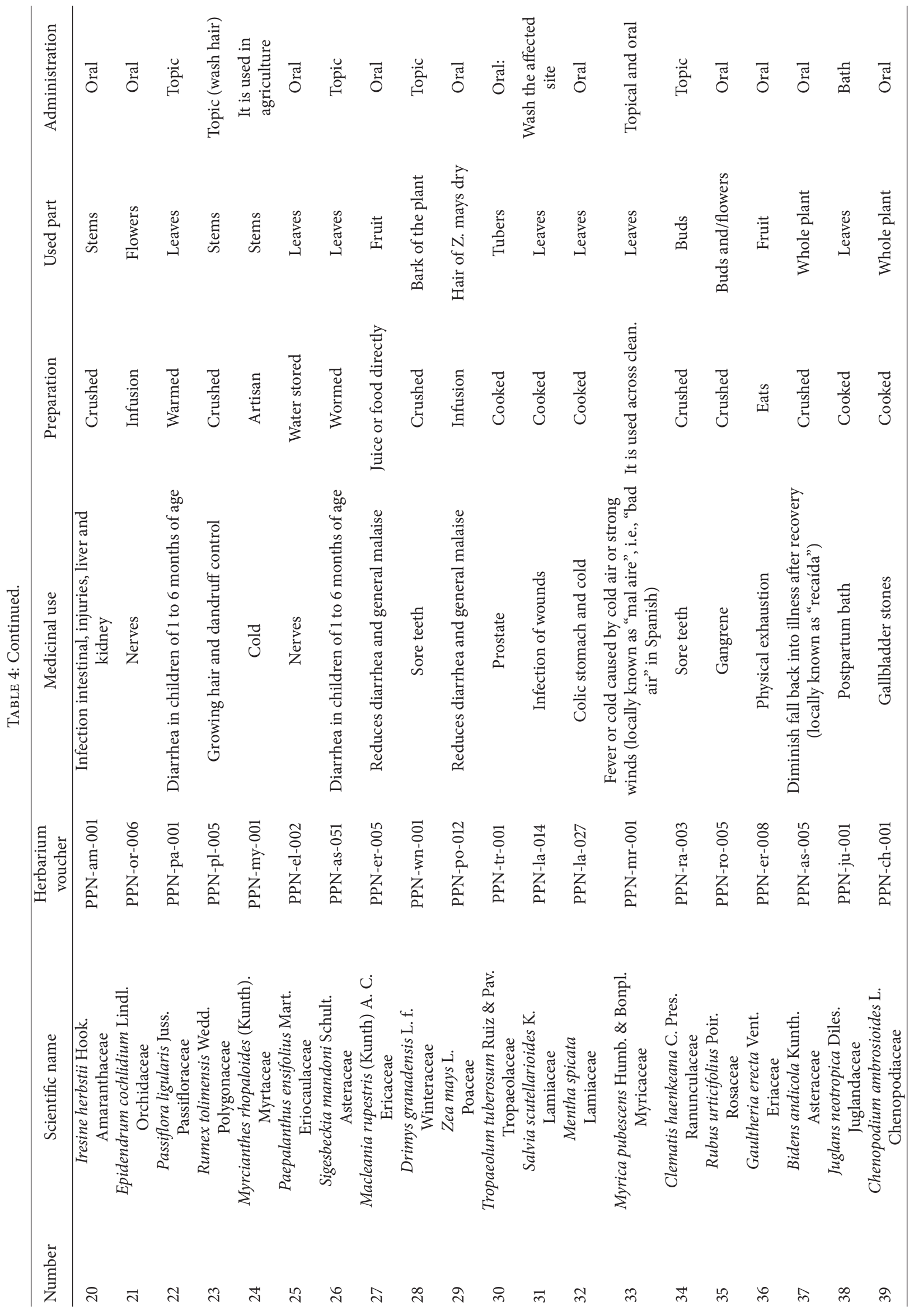




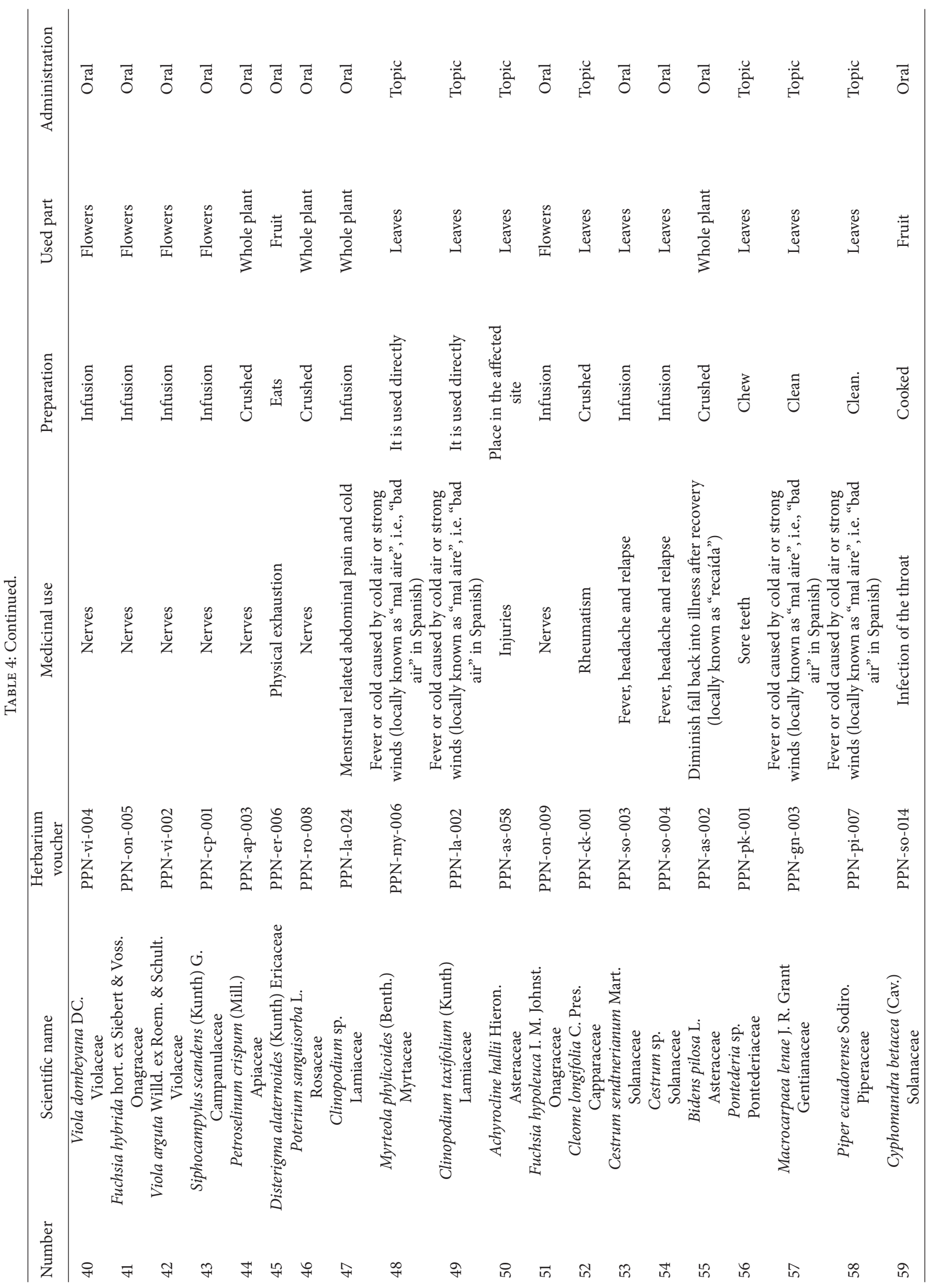




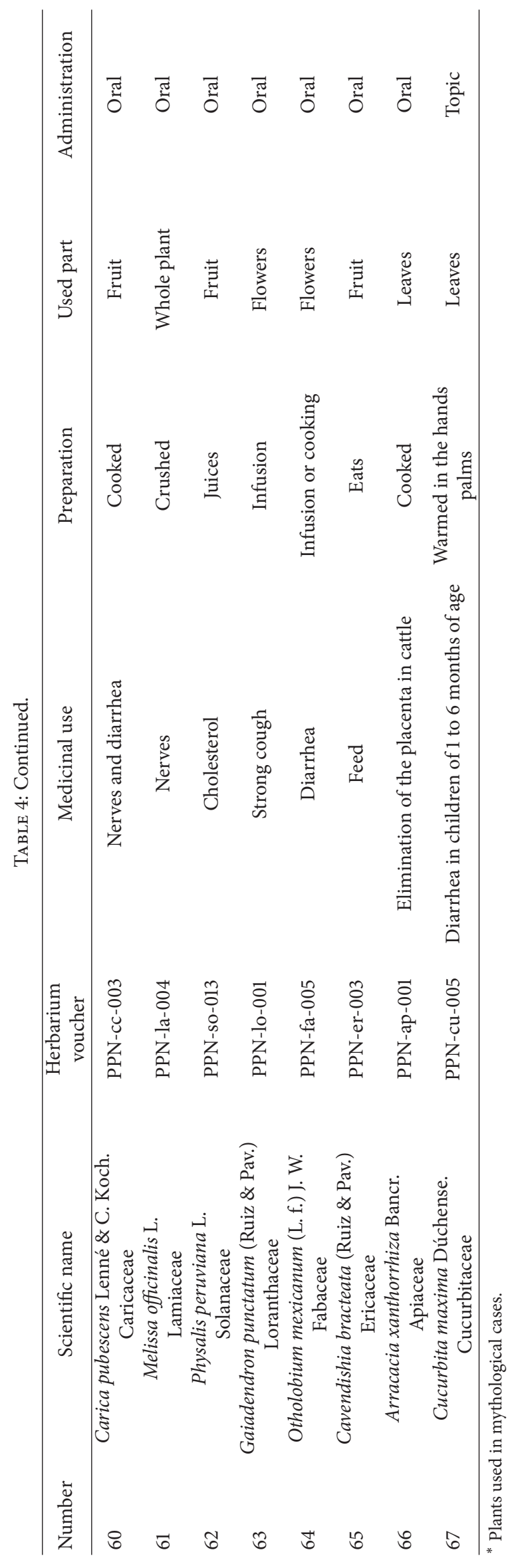




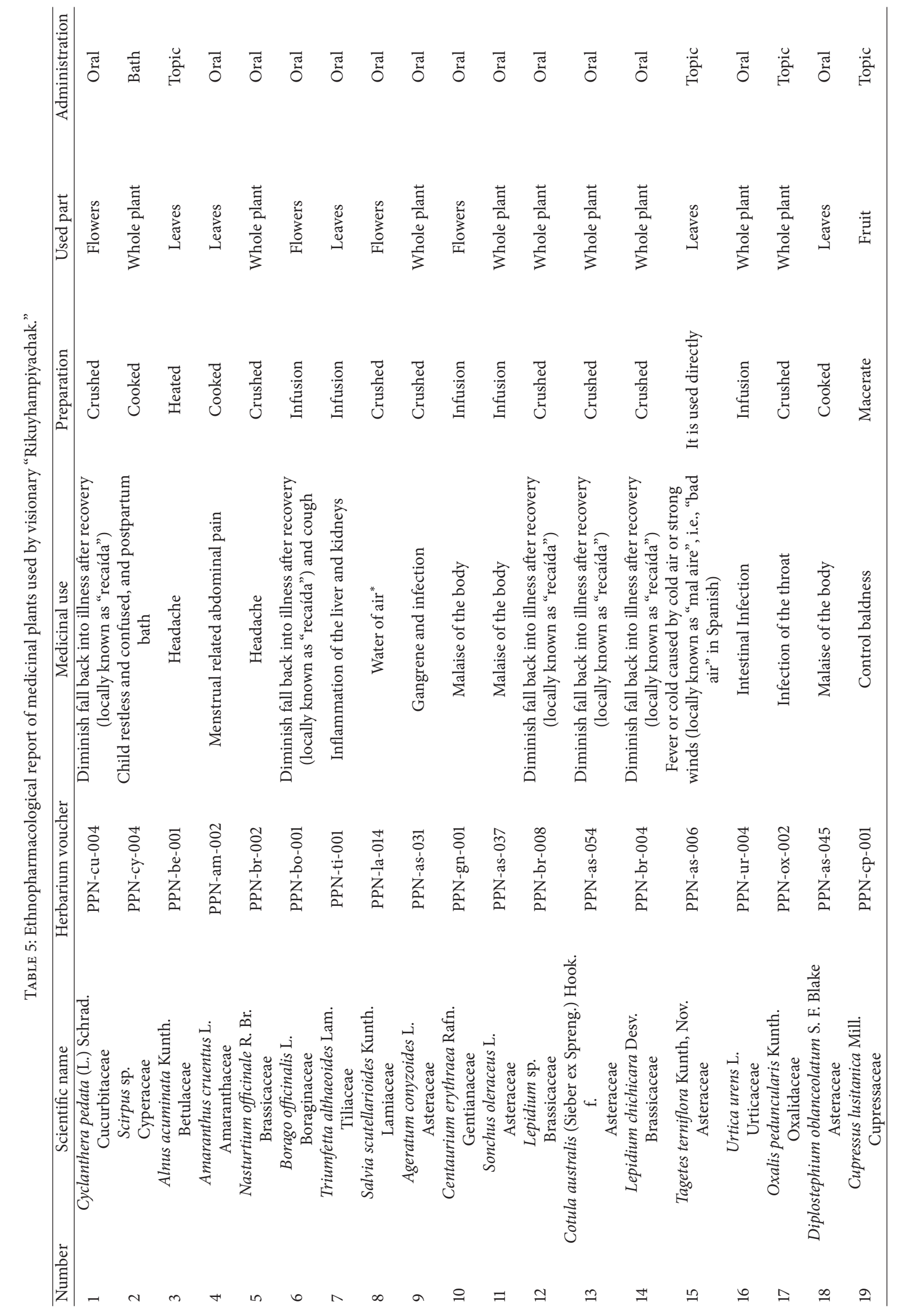




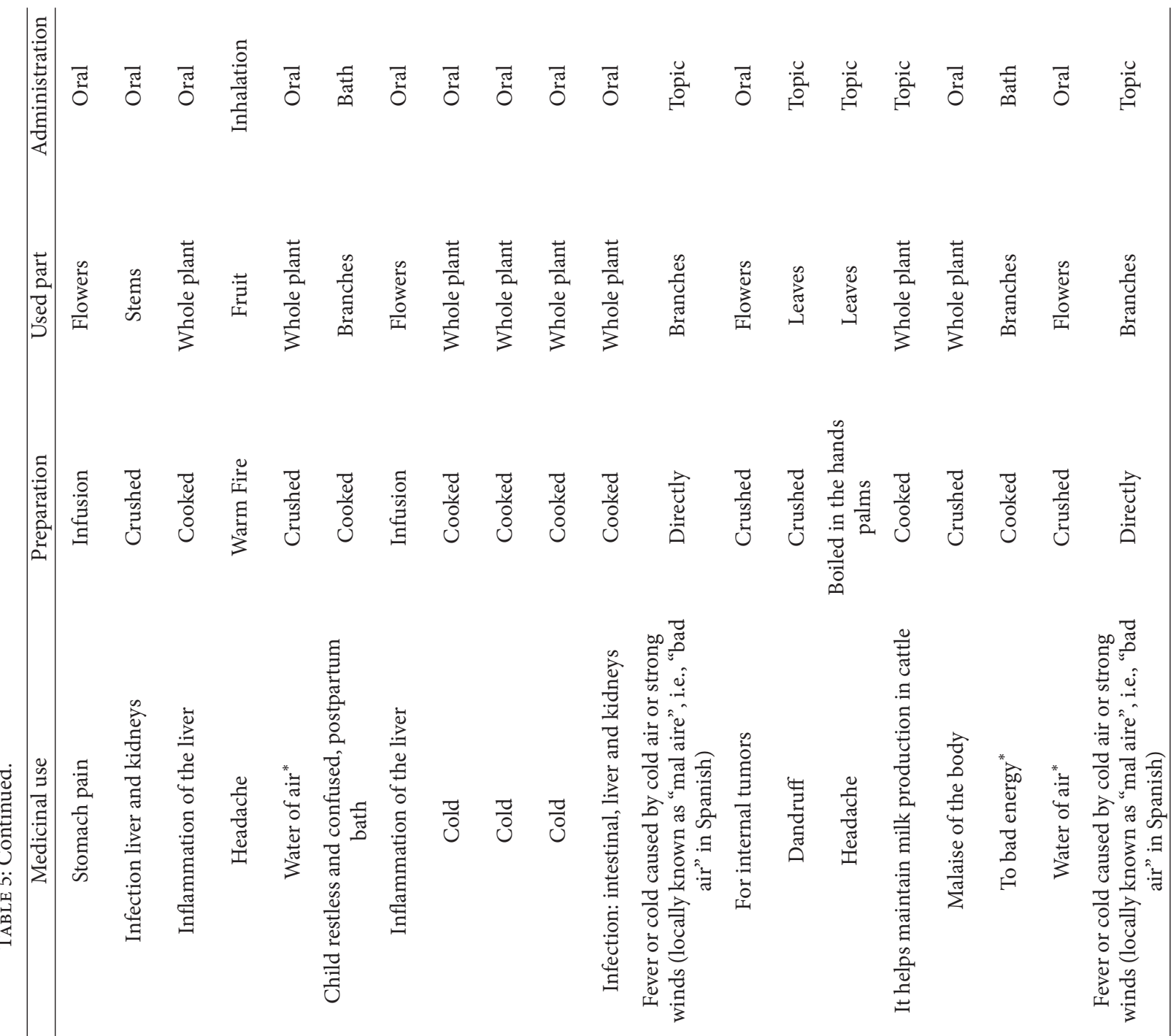

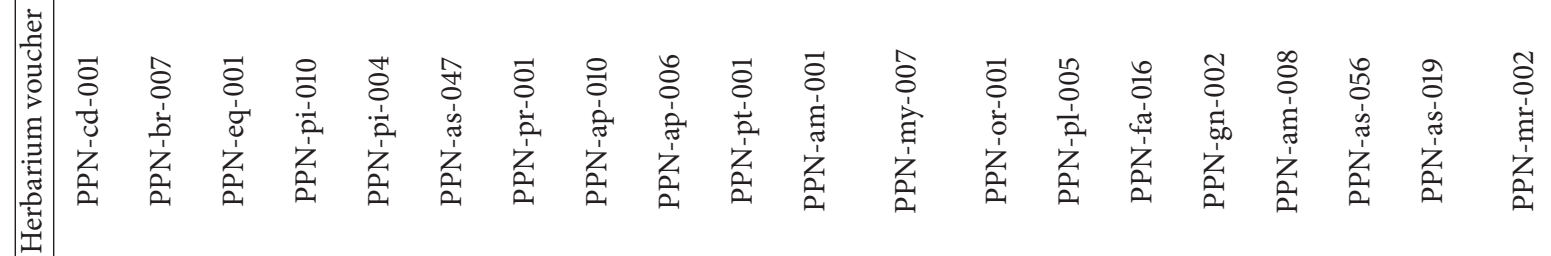
离

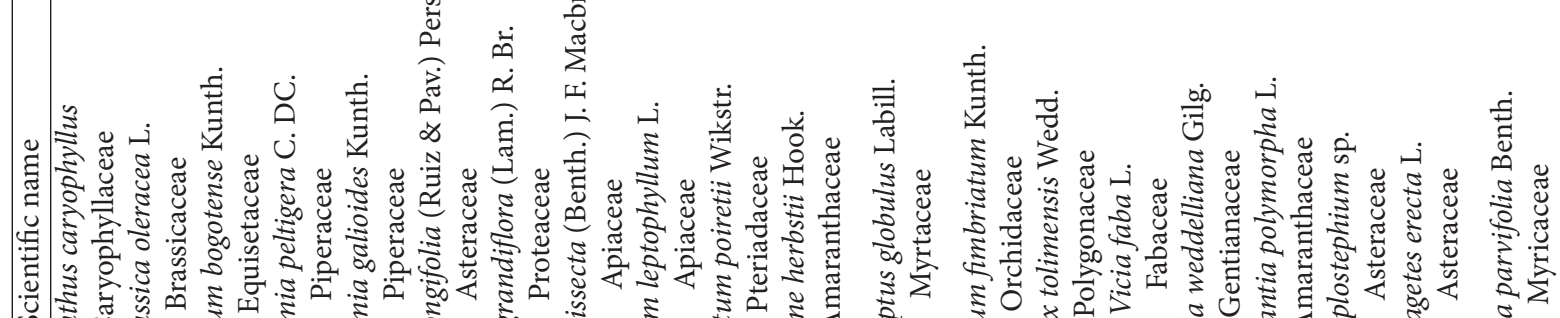

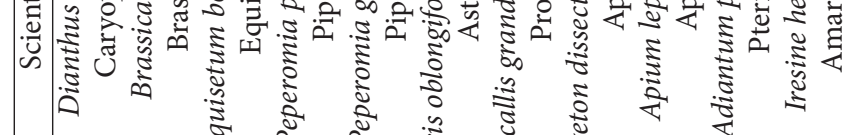

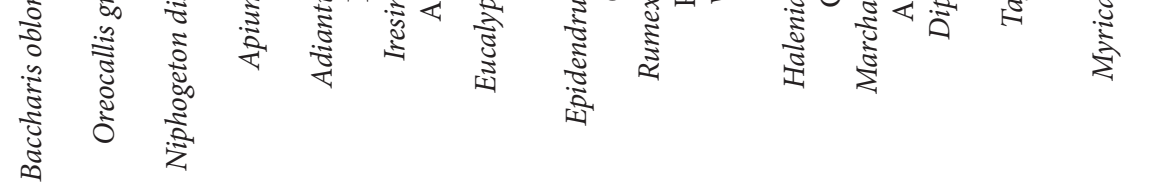

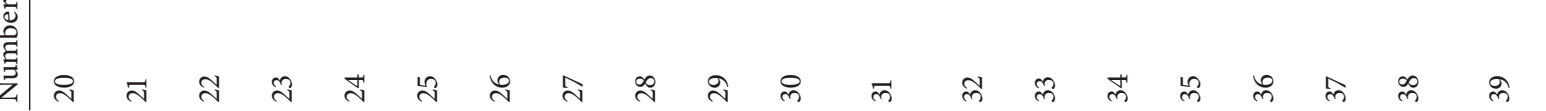




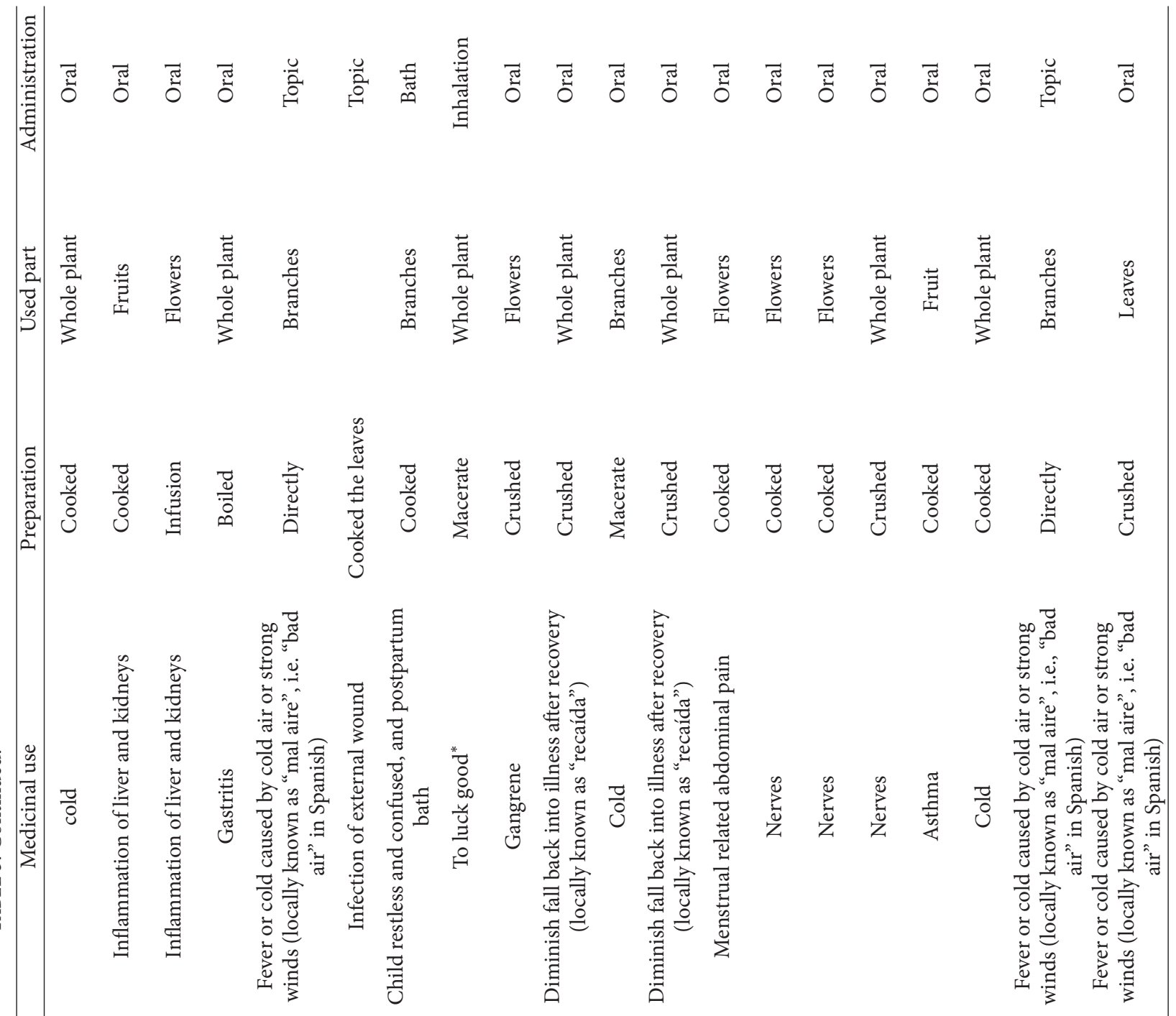

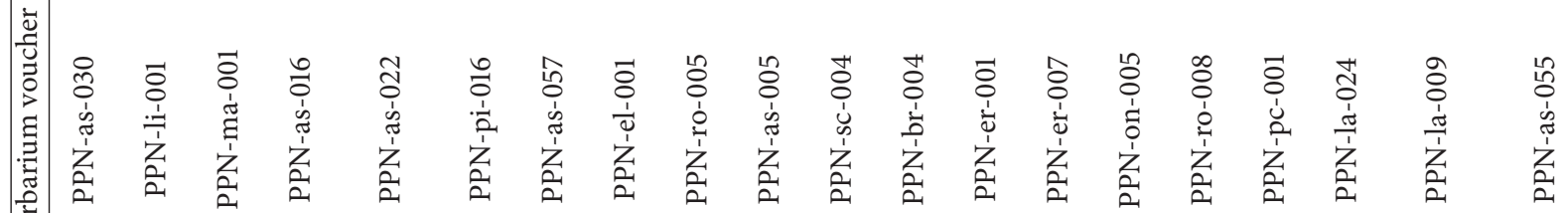

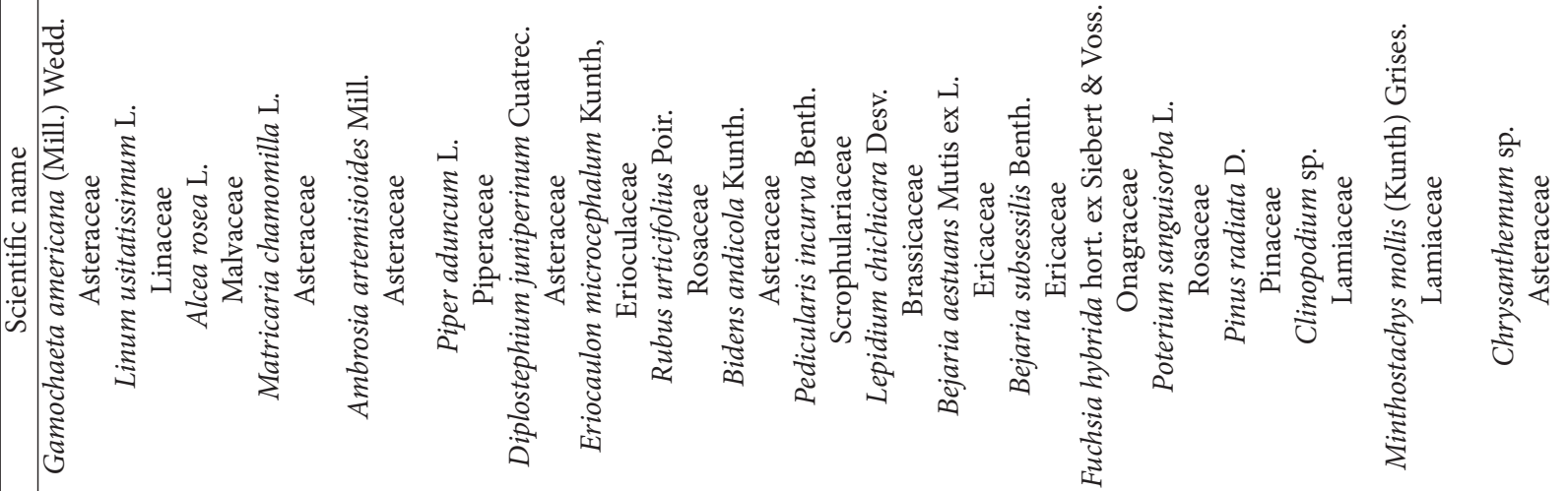




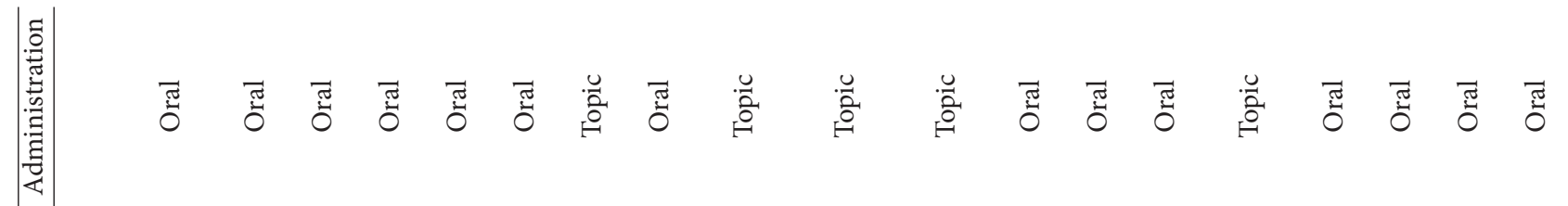

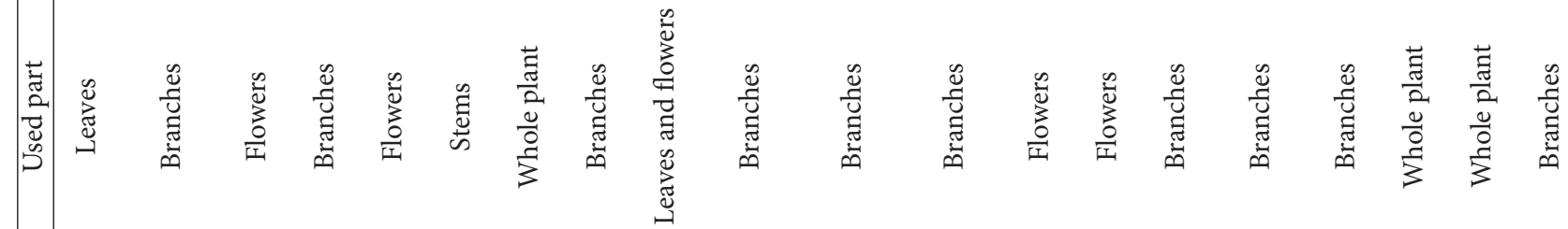

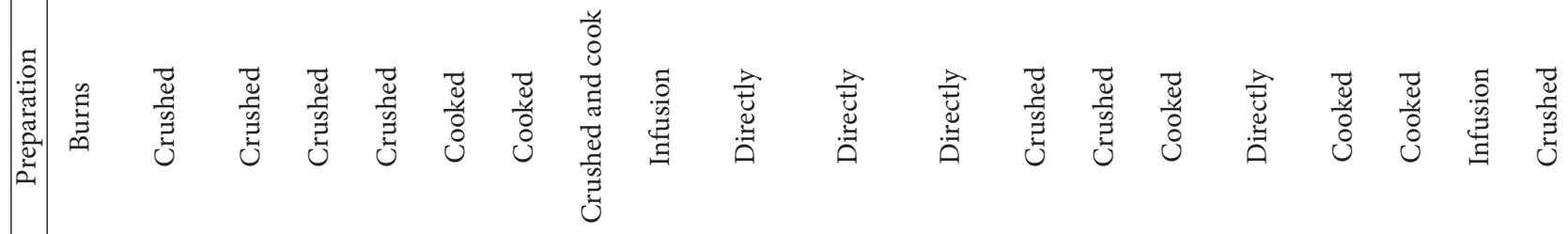

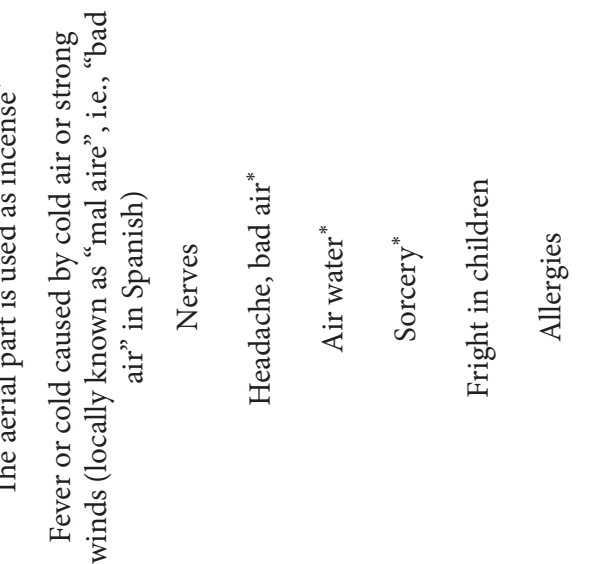

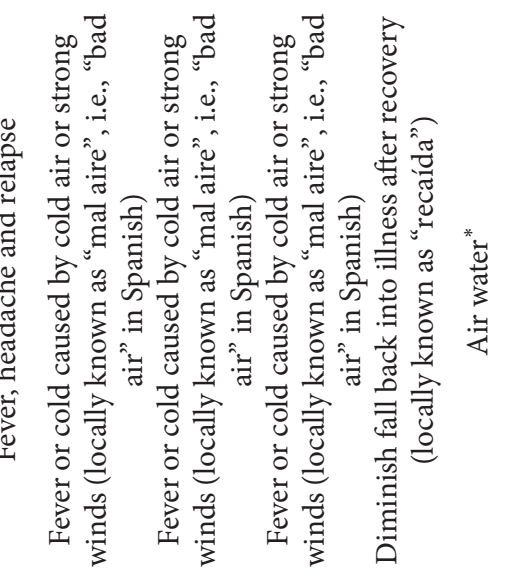

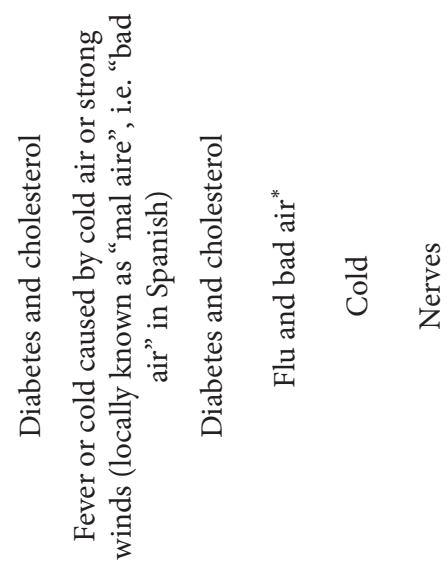

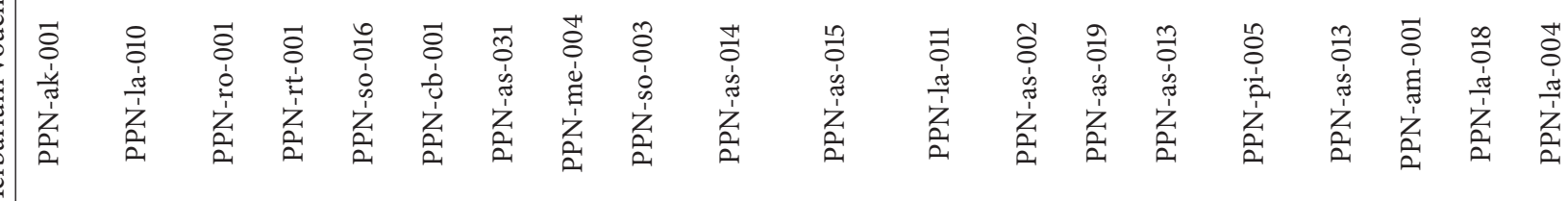

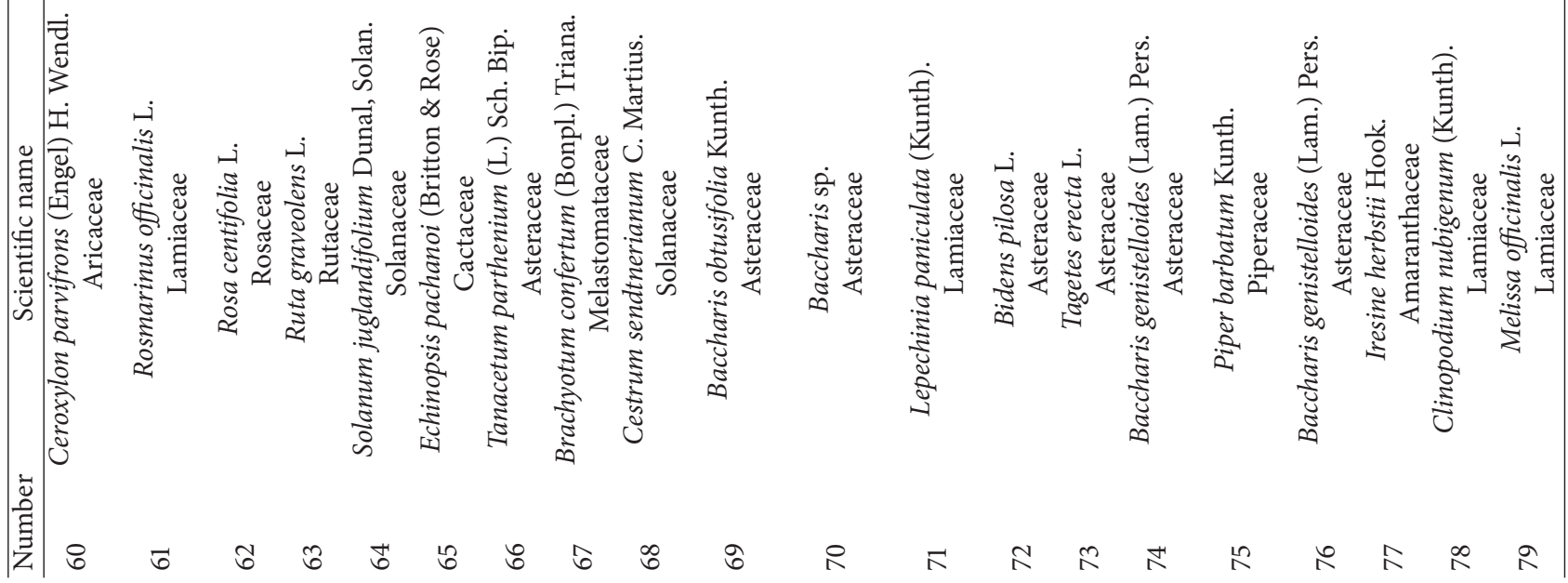




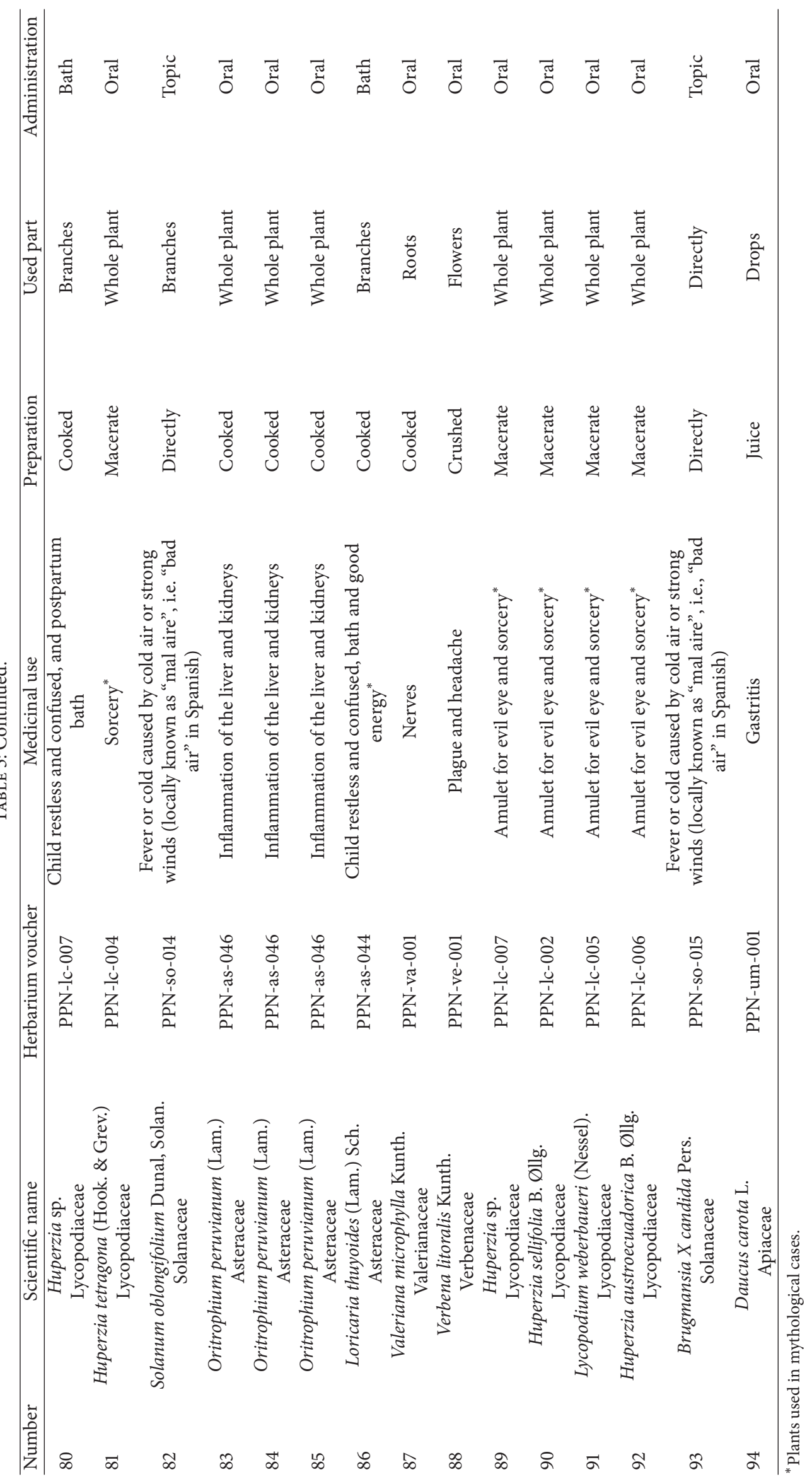




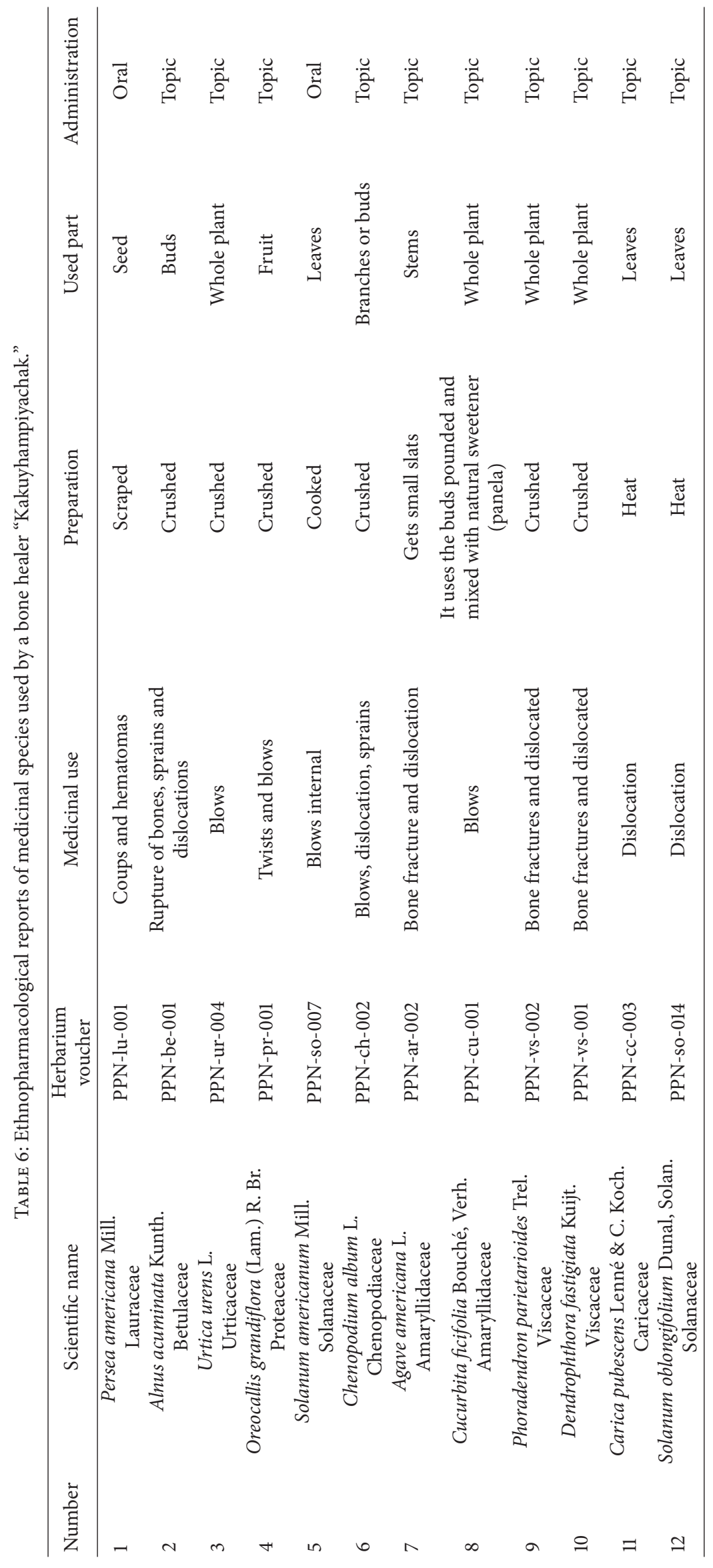




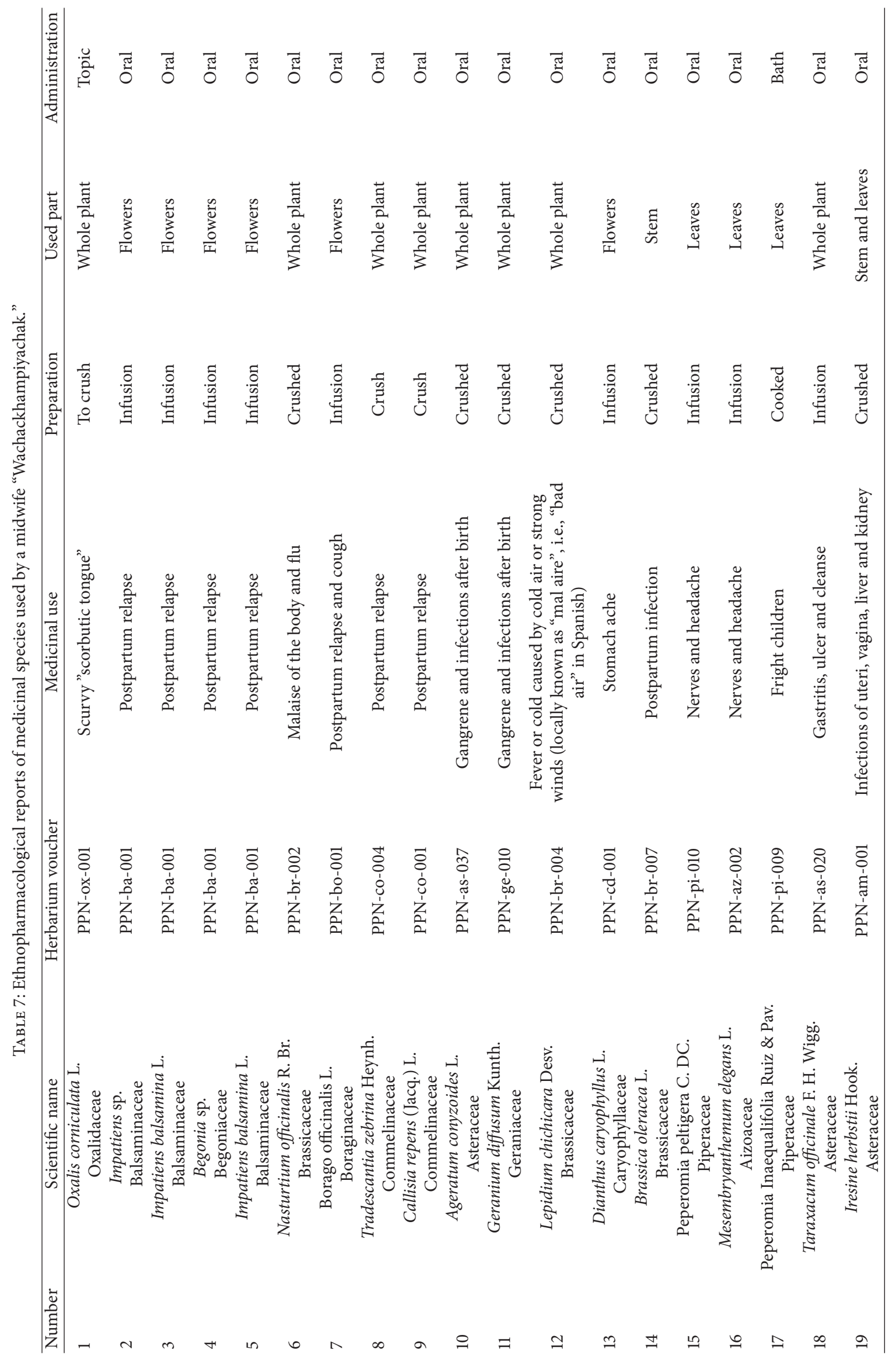




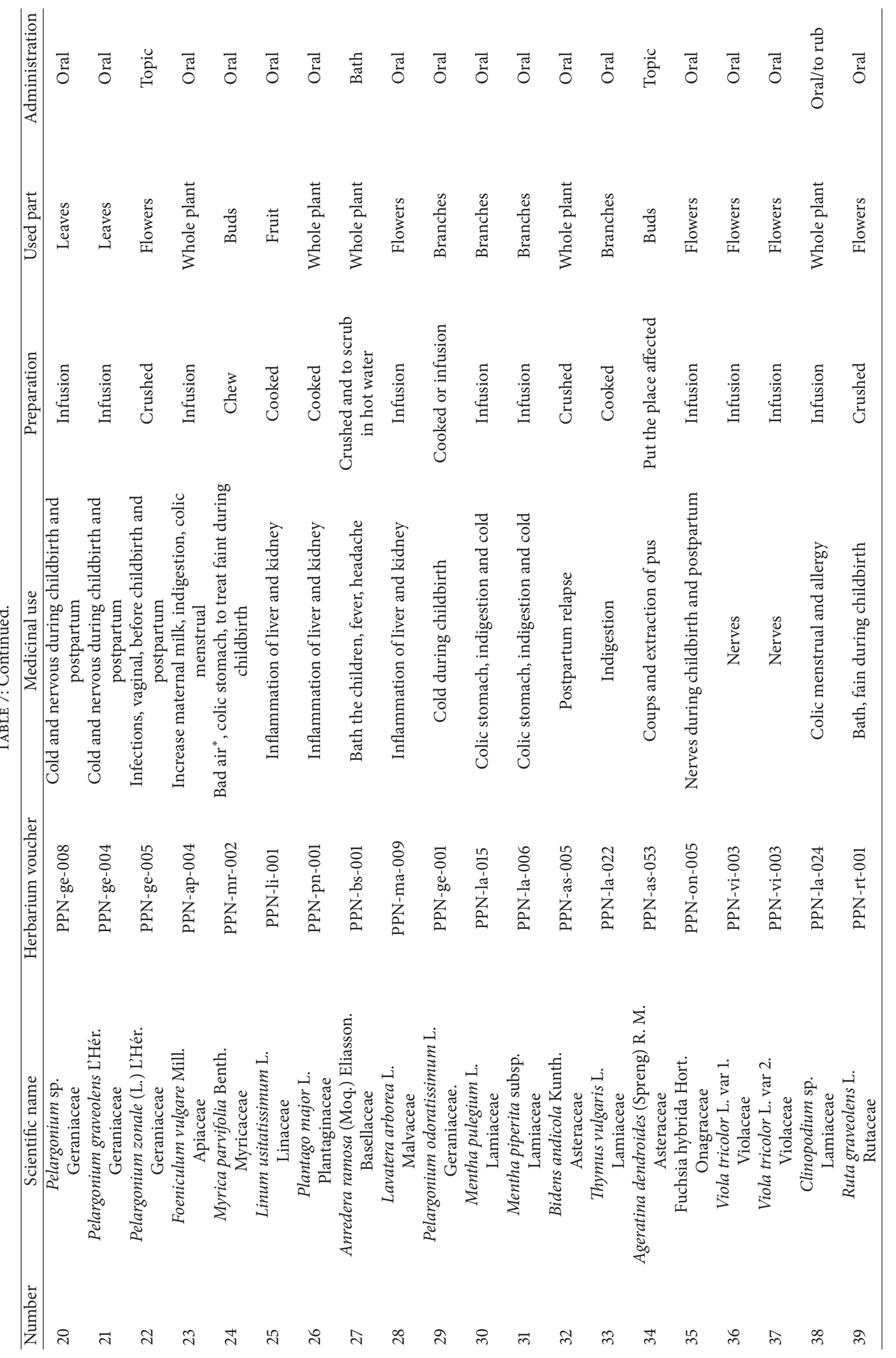




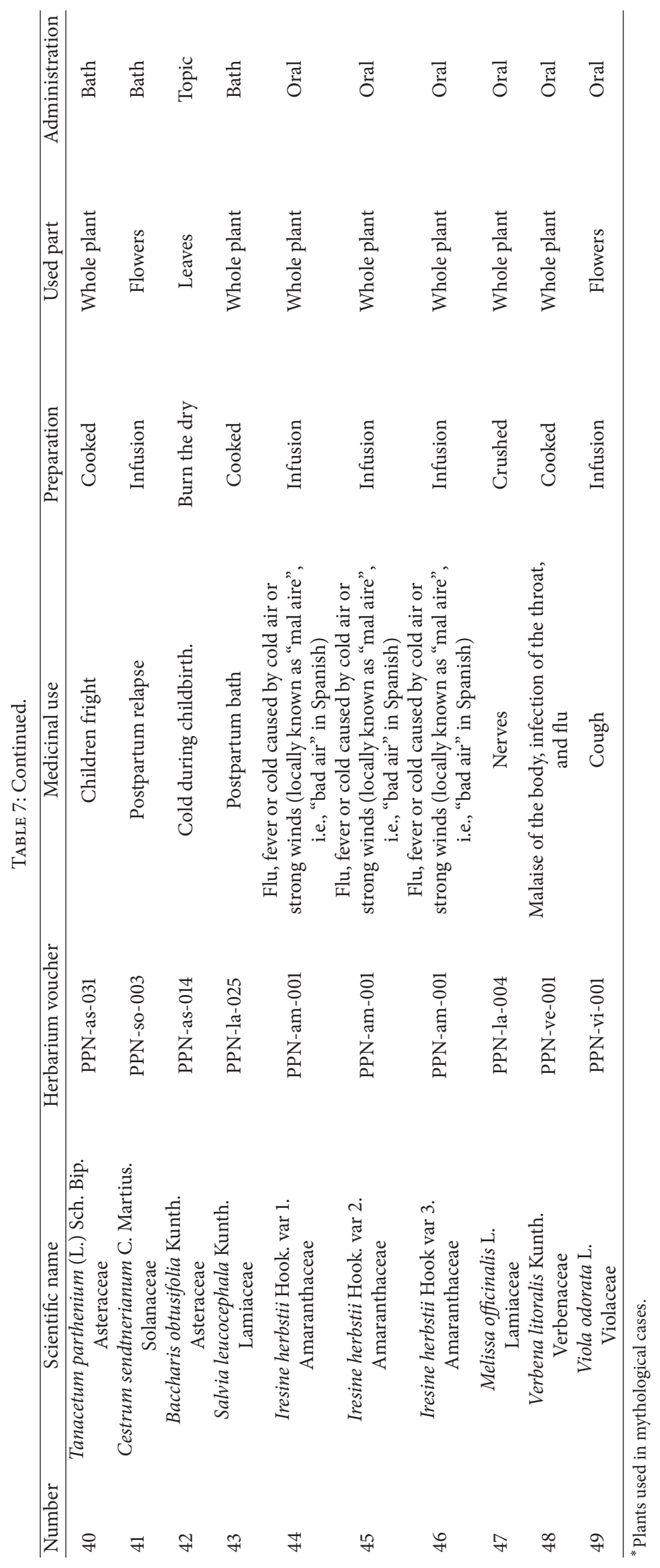




\section{Conflicts of Interest}

The authors declare that there are no conflicts of interest.

\section{Acknowledgments}

The authors thank the four key informants "Hampiyachakkuna" of the San Luca parish: Mama Aurelia, Taita Asunción, Taita Segundo, and Taita Vicente, whose openness to sharing their knowledge and wisdom was invaluable to carrying out this research. Special thanks are due to Bolivar Merino, curator of the Loja Herbarium. The authors thank the Universidad Técnica Particular de Loja (UTPL) for the financial support of this study. The authors are grateful to the Ministerio del Ambiente del Ecuador (MAE) for granting the permission for the collection of the documented species.

\section{References}

[1] M. A. X. Uhle, A Memoir of the Father of Peruvian Archaology, vol. 46, 1954, A memoir of the father of peruvian archaology.

[2] D. E. Ogburn, "Becoming saraguro: ethnogenesis in the context of inca and spanish colonialism," Ethnohistory, vol. 55, no. 2, pp. 287-319, 2008.

[3] R. D. Finerman, "Experience and expectation: conflict and change in traditional family health care among the quichua of saraguro," Social Science and Medicine, vol. 17, no. 17, pp. 12911298, 1983.

[4] V. Tene, O. Malagón, P. V. Finzi, G. Vidari, C. Armijos, and T. Zaragoza, "An ethnobotanical survey of medicinal plants used in Loja and Zamora-Chinchipe, Ecuador," Journal of Ethnopharmacology, vol. 111, no. 1, pp. 63-81, 2007.

[5] R. D. Finerman, "A matter of life and death: Health care change in an Andean community," Social Science and Medicine, vol. 18, no. 4, pp. 329-334, 1984.

[6] MSP-DPSL., Apuntes sobre medicina ancestral del pueblo Saraguro, Integraf, Ecuador, 2010.

[7] MSP-DPSL, El Uso de las Plantas Medicinales en las Prácticas Ancestrales de la Curacióny/o Sanación de Enfermedades de Pueblo Saraguro, Industrial Gráfica Amazonas, Ecuador, 2003.

[8] J. M. Andrade, C. Armijos, O. Malagón, and H. Lucero, Plantas Silvestres Empleadas por la etnia Saraguro en la Parroquia San Lucas, UTPL, Loja, Ecuador, 2009.

[9] R. Finerman, "Tracing home-based health care change in an Andean Indian community," Medical Anthropology Quarterly, vol. 3, no. 2, pp. 162-174, 1989.

[10] M. Rios, M. Koziol, P. Borgtoft, and G. Granda, Plantas útiles del Ecuador: aplicaciones retos yperspectivas/useful plants of Ecuador: aplication, challengens, and perspectives, Abya-Yala, Quito, Ecuador, 2007.

[11] C. Cerón, Manual de botánica ecuatoriana, Sistemática y métodos de estudio, Quito, Ecuador, 1993.

[12] A. Maldonado, P. Numa, F. Vivar, and J. Velez, Escenario Natural de La Cultura de Loja (Esbozo deGeografia Física y Humana), Casa de la Cultura Ecuatoriana, Núcleo de Loja, Consejo Nacional deCultura (Foncultura), Loja, Ecuador, 2005.

[13] E. W. Davis and J. A. Yost, "The ethnomedicine of the waorani of Amazonian Ecuador," Journal of Ethnopharmacology, vol. 9, no. 2-3, pp. 273-297, 1983.
[14] G. Frausin, R. B. S. Lima, A. D. F. Hidalgo, P. Maas, and A. M. Pohlit, "Plants of the annonaceae traditionally used as antimalarials: a review," Revista Brasileira de Fruticultura, vol. 36, no. 1, pp. 315-337, 2014.

[15] G. Iglesias, Sacha jambi: El uso de las plantas en la medicina tradicional de los Quichuas del Napo, Ab, Quito, Ecuador, 1989.

[16] P. Naranjo and R. Escaleras, La medicina tradicional en el Ecuador, 1st edition, 1995.

[17] F. Tinitana, M. Rios, J. C. Romero-Benavides, M. de la Cruz Rot, and M. Pardo-de-Santayana, "Medicinal plants sold at traditional markets in southern Ecuador," Journal of Ethnobiology and Ethnomedicine, vol. 12, no. 1, article no. 29, 2016.

[18] R. W. Bussmann and D. Sharon, "Two decades of ethnobotanical research in Southern Ecuador and Northern Peru," Ethnobiology and Conservation, vol. 3, no. 2014, article 3, 2014.

[19] V. Van Den Eynden, E. Cueva, and O. Cabrera, "Wild foods from Southern Ecuador," Economic Botany, vol. 57, no. 4, pp. 576-603, 2003.

[20] E. Béjar, R. Bussmann, and C. Roa, "Herbs of Southern Ecuador: a field guide to the medicinal plants of vilcabamba," Economic Botany, vol. 57, no. 1, pp. 161-162, 2001.

[21] R. W. Bussmann and D. Sharon, "Traditional medicinal plant use in Loja province, Southern Ecuador," Journal of Ethnobiology and Ethnomedicine, vol. 2, article 44, 2006.

[22] R. Finerman and R. Sackett, "Using home gardens to decipher health and healing in the Andes," Medical Anthropology Quarterly, vol. 17, no. 4, pp. 459-482, 2003.

[23] C. Armijos, I. Cota, and S. González, "Traditional medicine applied by the Saraguro yachakkuna: a preliminary approach to the use of sacred and psychoactive plant species in the Southern region of Ecuador," Journal of Ethnobiology and Ethnomedicine, vol. 10, no. 1, article no. 26, 2014.

[24] R. Ansaloni, I. Wilches, F. León et al., "Estudio Preliminar sobre Plantas Medicinales Utilizadas en Algunas Comunidades de las Provincias de Azuay, Cañar y Loja, para Afecciones del Aparato Gastrointestinal," Rev. Tecnológica, vol. 23, no. 1, pp. 89-97, 2010.

[25] S. León-Yánez, R. Valencia, N. Pitman, L. Endara, C. Ulloa Ulloa, and H. Navarrete, Libro rojo de las plantas endémicas del Ecuador, 2nd edition, 2011.

[26] P. Jorgensen and S. León-Yánez, Catalogue of the Vascular Plants of Ecuador, Missouri Botanical Garden Press, St. Louis, Mo, USA, 1999.

[27] V. Morocho, Estudio etnobotánico de especies medicinales en la comunidad indígena Saraguro de la Provincia de Loja, Universidad Técnica Particular de Loja, Loja, Ecuador, 2006.

[28] L. Jerves-andrade, F. León-tamariz, E. Peñaherrera, and N. Cuzco, "Medicinal plants used in South Ecuador for gastrointestinal problems?: an evaluation of their antibacterial potential," Journal of Medicinal Plants Research, vol. 8, no. 45, pp. 1310-1320, 2014.

[29] L. Jaramillo and R. Minga, Estudio etnobotánico en la Parroquia San Lucas, Cantón Loja, Provincia Loja, Universidad Técnica Particular de loja, Loja, Ecuador, 2006.

[30] A. Gerique, Biodiversity as a resource: plant use and land use among the shuar, saraguros, andmestizos in tropical rainforest areas of southern Ecuador, 2010.

[31] L. De la Torre, H. Navarrete, M. Muriel, M. Balslev, and H. Macía, Enciclopedia de las Plantas Útiles del Ecuador, 2008, Ecuador.

[32] C. Cerón, Plantas medicinales de los Andes ecuatorianos, 2006. 
[33] J. Izco, Í. Pulgar, Z. Aguirre, and F. Santin, "Estudio florístico de los páramos de pajonal meridionales de Ecuador," Revista Peruana de Biología, vol. 14, no. 2, pp. 237-246, 2013.

[34] A. I. Suárez, C. Armijos, J. M. Andrade et al., "The cytotoxic principle of Bejaria resinosa from Ecuador," Journal of Pharmacognosy and Phytochemistry, vol. 4, no. 3, pp. 268-272, 2015.

[35] C. Armijos, J. Ponce, J. Ramírez, D. Gozzini, P. V. I. Finzi, and G. Vidari, "An unprecedented high content of the bioactive flavone tricin in huperzia medicinal species used by the saraguro in Ecuador," Natural Product Communications, vol. 11, no. 3, pp. 273-274, 2016. 


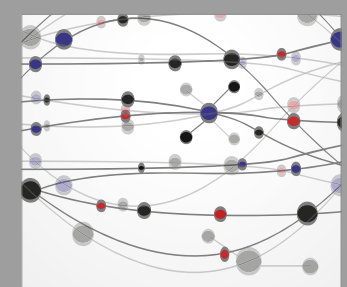

The Scientific World Journal
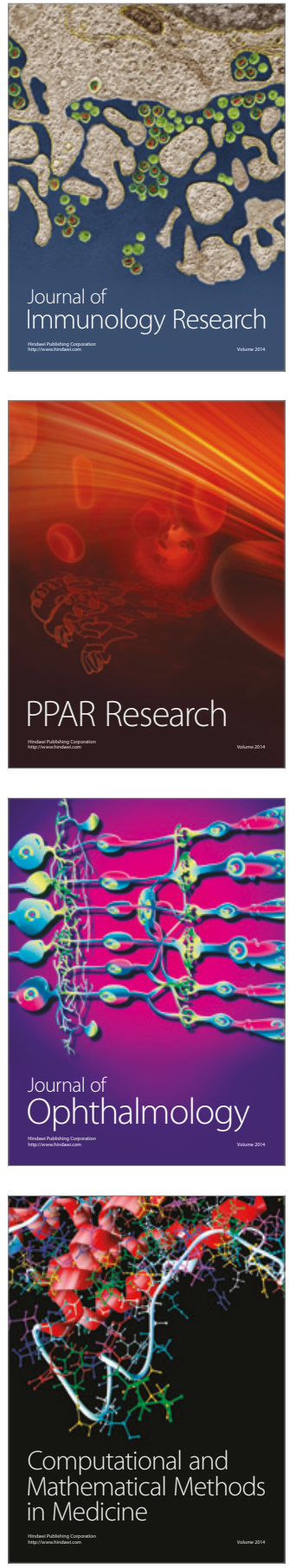

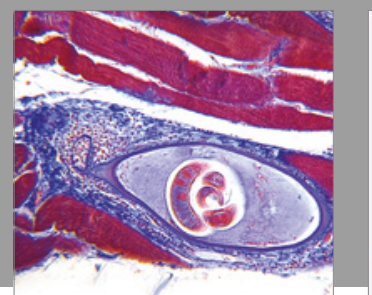

Gastroenterology Research and Practice
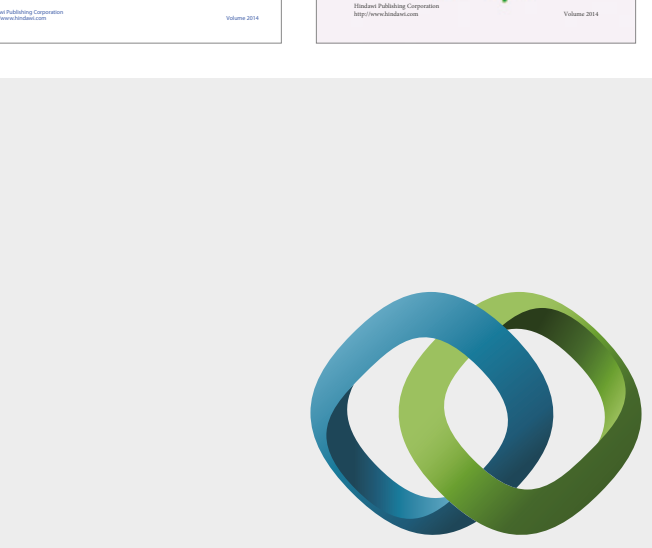

\section{Hindawi}

Submit your manuscripts at

https://www.hindawi.com
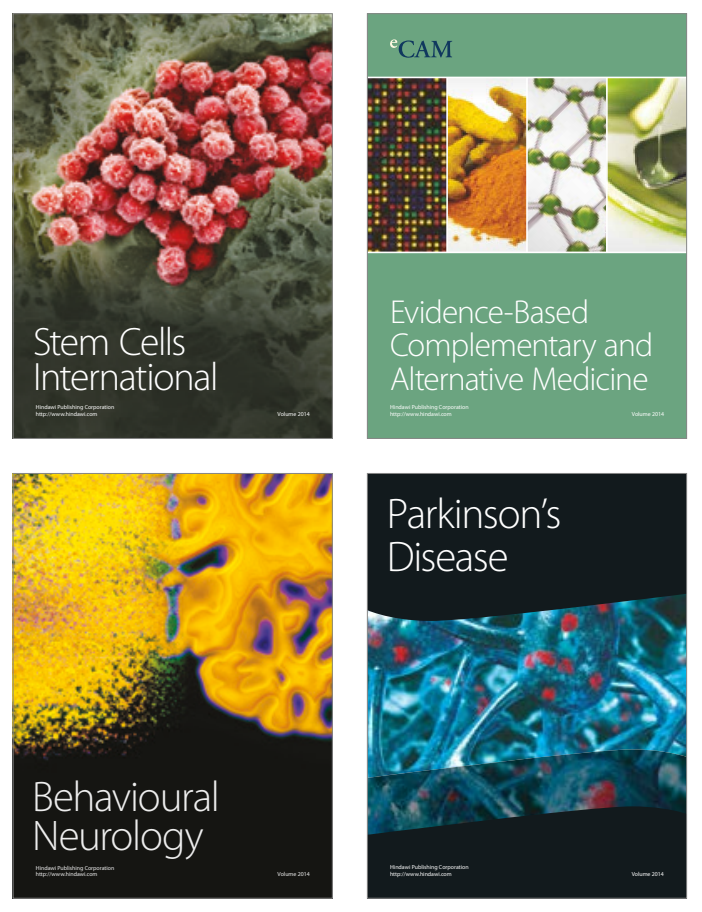
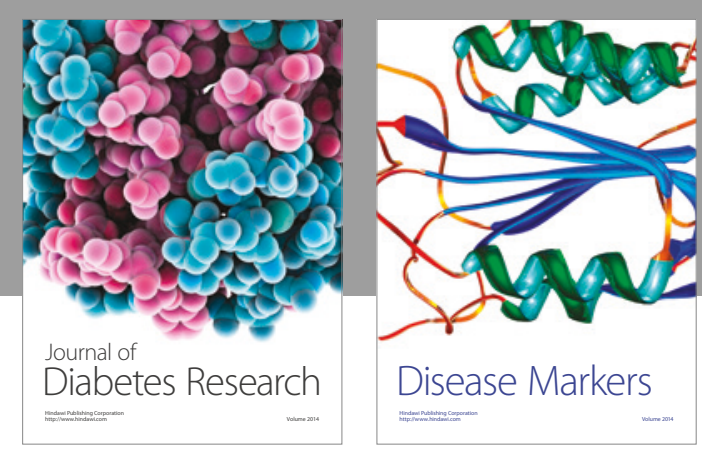

Disease Markers
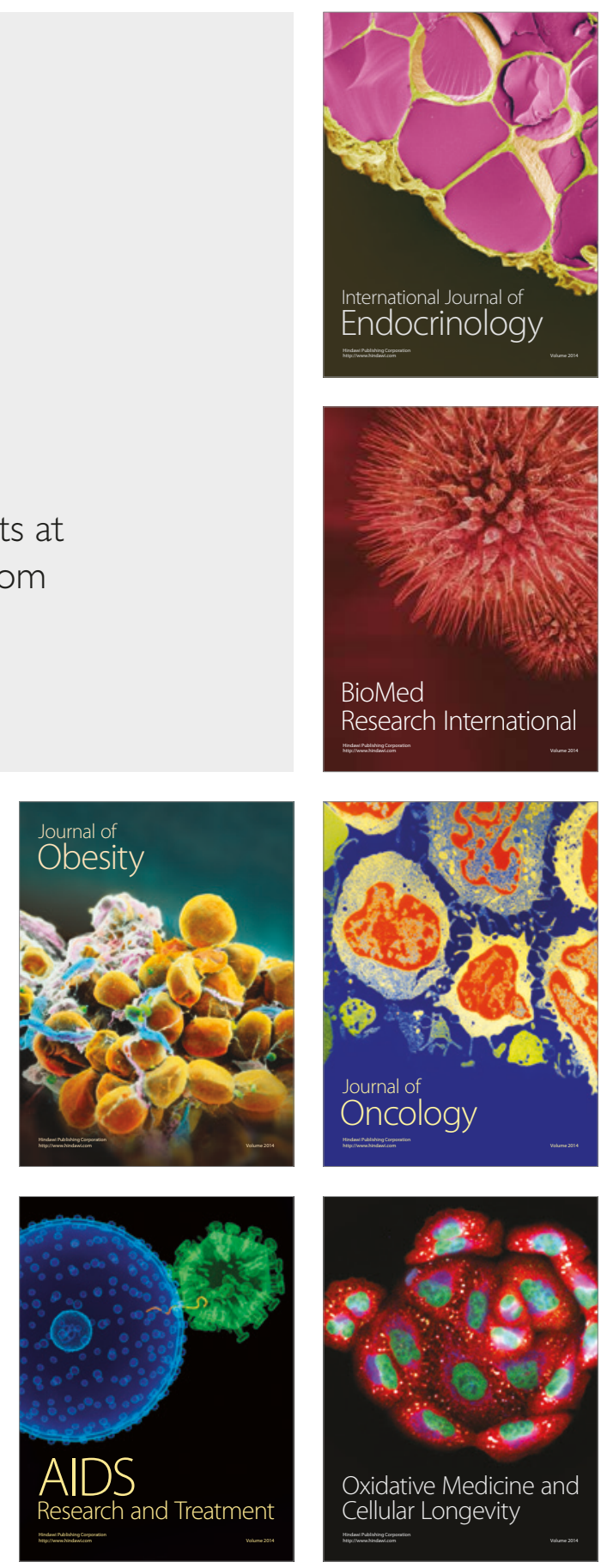